\title{
Performance of carrot genotypes at two Jequitinhonha Valley sites
}

\section{Desempenho de cultivares de cenoura em duas regiões distintas do Alto Vale do Jequitinhonha, MG}

\author{
Gustavo Antônio Mendes Pereira ${ }^{1 *}$; Maxwel Coura Oliveira ${ }^{2}$; \\ Altino Júnior Mendes Oliveira ${ }^{3}$; José Sebastião Cunha Fernandes ${ }^{4}$; \\ Valter Carvalho de Andrade Júnior ${ }^{4}$; Daniel Valadão Silva ${ }^{5}$; Evander Alves Ferreira ${ }^{6}$
}

\begin{abstract}
The successful commercial use of carrot depends on the choice of cultivars that are well-adapted to soil and climate conditions at the cultivation site and on good consumer acceptance. The objective of this study was to evaluate the performance of carrot cultivars grown in autumn-winter in two towns with different climatic characteristics, in the High Jequitinhonha Valley, MG, Brazil. The experiments were conducted on the Rio Manso farm, in the town of Couto de Magalhães de Minas and on Campus JK at UFVJM, in the town of Diamantina, Minas Gerais, Brazil. Six carrot cultivars (Brasília, Nantes, Kuronan, Esplanada, Planalto and Tornado) were evaluated using a randomized complete block design with three replicates. The following morpho-agronomic characteristics were evaluated 100 days after sowing: shoot height, root length, root dry matter, total dry matter, harvest index, commercial yield and total yield root. The most suitable cultivars in Diamantina were Planalto, Tornado and Kuronan, and the cultivatar Planalto was the best suited to Couto de Magalhães de Minas. The agronomic performance of the cultivars was higher in Couto de Magalhães de Minas for the majority of the study variables, resulting in a higher total yield and commercial root yield. The climatic and soil conditions of Diamantina induced flowering in most cultivars, causing a loss to the commercial yield in autumnwinter cultivation.
\end{abstract}

Key words: Environment, Daucus carota L., flowering, root yield

\section{Resumo}

O sucesso na exploração comercial da cenoura depende da escolha de cultivares com boa adaptação às condições de solo e de clima no local onde será cultivada e da boa aceitação pelo mercado consumidor. O objetivo do presente trabalho foi avaliar o desempenho de cultivares de cenoura no cultivo de outono-inverno em dois municípios com características edafoclimáticas distintas do Alto Vale do Jequitinhonha, MG. Os experimentos foram conduzidos na Fazenda Rio Manso, município de Couto de Magalhães de Minas, MG e no Campus JK da UFVJM, município de Diamantina, MG. Foram avaliadas seis cultivares de cenoura (Brasília, Nantes, Kuronan, Esplanada, Planalto e Tornado) utilizando-se o delineamento experimental em blocos ao acaso com três repetições. As características

${ }^{1}$ Discente de Doutorado, Universidade Federal de Viçosa, UFV, Viçosa, MG, Brasil. E-mail: gustavogamp@hotmail.com

2 Discente, University of Nebraska-Lincoln, UNL, Lincoln, NE, Estados Unidos da América. E-mail: maxwelco@gmail.com

${ }^{3}$ Discente de Graduação em Agronomia, Universidade Federal dos Vales do Jequitinhonha e Mucuri, UFVJM, Diamantina, MG, Brasil. E-mail: altinojrmendes@gmail.com

${ }^{4}$ Profs., Universidade Federal dos Vales do Jequitinhonha e Mucuri, UFVJM, Diamantina, MG, Brasil. E-mail: cunha.fernandes@ ufvjm.edu.br; valterjr15@gmail.com

5 Prof., Universidade Federal Rural do Semi-Árido, UFERSA, Mossoró, RN, Brasil. E-mail: danielvaladaos@yahoo.com.br

6 Pesquisador, UFVJM, Diamantina, MG, Brasil. E-mail: evanderalves@gmail.com

* Author for correspondence 
morfoagronomicas altura da parte aérea, comprimento de raiz, matéria seca de raiz, matéria seca total, índice de colheita, produtividade comercial e produtividade total de raízes foram avaliadas 100 dias após a semeadura. As cultivares que se destacaram em Diamantina foram Planalto, Tornado e Kuronan e em Couto de Magalhães de Minas a cultivar Planalto. O desempenho agronômico das cultivares foi superior em Couto de Magalhães de Minas para a maioria das variáveis avaliadas, resultando em uma maior produtividade total e comercial de raízes. As condições edafoclimáticas de Diamantina induzem florescimento na maioria das cultivares, causando perdas de produtividade comercial no cultivo de outono-inverno.

Palavras-chave: Ambiente, Daucus carota L., florescimento, produtividade de raiz

\section{Introduction}

In terms of consumption, extension of planting area and socioeconomic value, carrots (Daucus carota $\mathrm{L}$.) are among the most important herbaceous crops in the world (FREITAS et al., 2009). They are currently the fourth most widely cultivated vegetable in Brazil, with an estimated production of 756,000 tones and mean yield of 28 t.ha $^{-1}$ (EMBRAPA, 2013). This yield can be considered low when compared to Brazilian regions such as Gotardo, MG and Brasilia, DF, where the yield can exceed 80 t.ha $^{-1}$ of roots (EMBRAPA, 2012). This occurs because these regions apply appropriate management practices for carrot crops; in addition, yellow-reddish Latosol soil predominates in both towns, which is conducive to the development of tuberous roots (OLIVEIRA et al., 2005).

The carrot is a species that grows a in mild climate; after Brazilian cultivars (considered as summer cultivars) were launched on the market, carrots began to be cultivated in Brazil virtually all year round (SILVA et al., 2012). The main summer cultivars available on the market are Brasilia, Kuronan, Prima, Nova Carandaí, and the main winter cultivar is Nantes (EMBRAPA, 2015). However, factors such as temperature, relative humidity, photoperiod, harvesting season, preference of the consumer market and time of sowing, must be observed in the choice of a cultivar that is suitable for each region, in order to obtain success in the commercial use of their roots (DUDA; REGHIN, 2000).

Typically, the cultivars imported from Nantes are usually grown in the autumn and winter, whereas in the spring and summer, the Brazilian cultivars Kuronan, Brasilia, Kuroda and more recently, the cultivars Prima, Esplanada and Planalto are cultivated (REGHIN; DUDA, 2000; VIEIRA et al., $2005,2012)$. This division is due to high bolting rates of Brazilian cultivars when they are planted in cold seasons, and also due to the high incidence of diseases in the leaves and the low resistance to heat of imported cultivars when sowing occurs in warm seasons.

The choice of genotypes for extensive ranges of environments on the basis of their mean yield, i.e., without considering the specific adaptation of each genotype in each environment, is a decision that facilitates the work of plant breeders. However, for productive characteristics where the effects of the genotype-environment interaction are important, this practice can cause large losses, because these interactions are not defined for each specific environment. This is one reason why it can be difficult to select genotypes for regions that have different soil and climatic features (CRUZ; CASTOLDI, 1991).

Within the same agricultural area, climatic differences can exist at different locations, whose ecological conditions are apparently similar. The effects of these differences on the performance of a particular crop can be evaluated by genotypeenvironment interactions. Therefore, before making final recommendations for genotypes on different sites, tests should be conducted at different times and at different locations, in order to verify the respective crop agronomic performance (LARIOS et al., 1992). 
The objective of this study was to evaluate the performance of carrot cultivars grown in autumnwinter in two towns of the High Jequitinhonha Valley, MG, with different climatic characteristics.

\section{Material and Methods}

The study was carried out in the field in two locations: (a) The Rio Manso Experimental Farm, Universidade Federal dos Vales do Jequitinhonha e Mucuri - UFVJM, located in the town of Couto de Magalhães, Minas Gerais, (18 $07^{\prime} \mathrm{S}$ and $43^{\circ} 47^{\prime} \mathrm{W}$; $726 \mathrm{~m}$ altitude), with a mean annual rainfall of 1,269 mm (CPRM, 2013) and a mean annual temperature of $19.4^{\circ} \mathrm{C}$, with a climate classified as Aw, according to the Köppen classification, i.e., tropical climate with dry winter season, and a clayey and generally poorly drained soil classified as Dystrophic Typic Hapludox; b) The Department of Olericulture, UFVJM Campus JK, located in the town of Diamantina, Minas Gerais, (18 $12^{\prime} \mathrm{S}$ and $43^{\circ} 34^{\prime} \mathrm{W}$; $1,387 \mathrm{~m}$ altitude) with a mean annual temperature of $18^{\circ} \mathrm{C}$, a mean annual rainfall of $1,404.7 \mathrm{~mm}$, with a Cwb climate, according to the Köppen classification, i.e., humid temperate, with a dry winter and rains in the summer, located on a sandy and moderately drained Typic Orthic Quartzarenic Neosol. Table 1 shows the minimum, maximum, and median temperatures and the rainfall, evaluated during the given period for the two towns.

Table 1. Maximum, minimum and mean temperatures $\left({ }^{\circ} \mathrm{C}\right)$ and rainfall $(\mathrm{mm})$, during the period of the experiments for the cities of Diamantina, MG and Couto de Magalhães de Minas, Minas Gerais, for May to November 2011. Data are from INMET. UFVJM, Diamantina, 2013.

\begin{tabular}{|c|c|c|c|c|c|c|c|c|}
\hline \multirow{2}{*}{ Variable } & \multirow{2}{*}{ City } & \multicolumn{7}{|c|}{ Year 2011} \\
\hline & & May & Jun & Jul & Aug & Sep & Oct & Nov \\
\hline \multirow{2}{*}{$\begin{array}{l}\text { Maximum } \\
\text { temperature }\end{array}$} & Diamantina & 21.5 & 22.2 & 22.3 & 25.4 & 25.2 & 23.1 & 22.8 \\
\hline & Couto de M. & 25.2 & 26.4 & 26.6 & 29.5 & 29.1 & 27.1 & 26.2 \\
\hline \multirow{2}{*}{$\begin{array}{l}\text { Minimum } \\
\text { temperature }\end{array}$} & Diamantina & 11.4 & 12.1 & 11.4 & 13.0 & 12.5 & 14.5 & 14.3 \\
\hline & Couto de M. & 12.0 & 12.1 & 10.9 & 11.3 & 11.5 & 16.9 & 17.2 \\
\hline \multirow{2}{*}{$\begin{array}{c}\text { Mean } \\
\text { temperature }\end{array}$} & Diamantina & 16.5 & 17.1 & 16.9 & 19.2 & 18.8 & 18.8 & 18.6 \\
\hline & Couto de M. & 18.6 & 19.2 & 18.7 & 20.4 & 20.3 & 22.0 & 21.7 \\
\hline \multirow{2}{*}{ Rainfall } & Diamantina & 0.4 & 0.3 & 0.01 & 0.5 & 0.1 & 178.8 & 342.5 \\
\hline & Couto de M. & 0.3 & 0.01 & 5.7 & 0.01 & 0.01 & 82.6 & 269.4 \\
\hline
\end{tabular}

Source: INMET, 2012.

The experimental design consisted of a plots consisted of an area of $2 \mathrm{~m}^{2}$, with four rows randomized block design, with three replicates. The treatments included six carrot cultivars (Brasília, Nantes, Kuronan, Esplanada, Planalto and Tornado). The experimental areas were plowed and harrowed, and seedbeds were then created. The spaced $0.24 \mathrm{~m}$ apart. The correction of acidity and soil fertilization were performed according to the results of soil analysis in the experimental areas (Table 2), following the criteria of the Commission for Soil Fertility of the State of Minas Gerais (CFSEMG, 1999). 
Table 2. Chemical composition and physical soil samples from the $0-20 \mathrm{~cm}$ soil depth layer in the cities of Diamantina, MG and Couto de Magalhães de Minas, MG. UFVJM, Diamantina, 2013.

\begin{tabular}{|c|c|c|c|c|c|c|c|c|c|c|}
\hline City & $\mathrm{pH}$ & $\mathrm{P}$ & $\mathrm{K}$ & $\mathrm{Ca}$ & $\mathrm{Mg}$ & $\mathrm{Al}$ & $\mathrm{H}+\mathrm{Al}$ & SB & $\mathrm{T}$ & $\mathrm{t}$ \\
\hline & & \multicolumn{2}{|c|}{ mg.dm ${ }^{-3}$} & \multicolumn{7}{|c|}{ cmolc.dm ${ }^{-3}$} \\
\hline Diamantina & 5.6 & 2.49 & 12.6 & 0.7 & 0.45 & 0.12 & 1.9 & 1.18 & 3.08 & 1.3 \\
\hline Couto de M. & 5 & 6.1 & 111 & 2.4 & 1.2 & 0.02 & 2.4 & 3.89 & 6.29 & 3.91 \\
\hline \multirow{3}{*}{ City } & & & & & & & & \multicolumn{3}{|c|}{ Granulometry } \\
\hline & V & $\mathrm{Fe}$ & $\mathrm{Cu}$ & $\mathrm{Zn}$ & $\mathrm{Mn}$ & B & & Sand & Silt & Clay \\
\hline & $\%$ & & & $\mathrm{mg} \cdot \mathrm{dm}^{-1}$ & & & & & $\%$ & \\
\hline Diamantina & 38 & 202 & 0.59 & 4.41 & 1.89 & 2.09 & & 86 & 3 & 11 \\
\hline Couto de M. & 62 & 43.3 & 1.28 & 1.2 & 233 & 0.14 & & 60 & 13 & 27 \\
\hline
\end{tabular}

Seeding was performed in the two locations on 26 August, 2011, and the experiments were irrigated twice daily during the entire crop cycle. Thinning was performed at 35 days after sowing, maintaining a 5-cm distance between plants within each row.

For the analysis of final yield, 10 plants per plot were harvested at 100 days after sowing (mean date of harvest of cultivars), and were evaluated for the following characteristics: shoot height $(\mathrm{H})$; root length (LEN); root diameter (RD); root dry matter (RDM), total dry matter (TDM); harvest index (HI) $=($ economic yield $/$ biological yield $) \times 100$; and total yield (TY). The harvest index (HI) was calculated using the following formulae (FLOSS, 2006):

Biological yield $(\mathrm{BY})=$ total dry matter $(\mathrm{kg}) \times$ number of plants per ha; and

Economic yield $(E Y)=$ root dry matter $(\mathrm{kg}) \times$ number of plants per ha.

Shoot height and root length were measured using a graduated ruler. Subsequently, the collected plant material was washed in distilled water, weighed and dried in an air-forced circulation oven at $70^{\circ} \mathrm{C}$ to constant weight. Root dry matter and total dry matter were determined using $0.0001 \mathrm{~g}$ precision electronic scales. Total dry matter was calculated by summing the shoot and the root dry matter.

Total yield was calculated as the mean root production, measured on the evaluated plants, multiplied by the number of plants in one hectare.
The results were expressed in t.ha ${ }^{-1}$. For this characteristic, the roots that had flourished were also taken into account.

The data were submitted to an analysis of covariance, and the means, when significant, underwent the $F$-test, and were subsequently compared by Tukey's test at 5\% probability.

The flowering percentage (\% FLO) was also evaluated at 100 days after sowing; this is the ratio between the total number of plants whose seed stalk has appeared and the total number of plants in the plot. For the calculation of commercial yield (CY), the roots of plants that were flowering were excluded from the total root yield, and the flowering percentage and commercial yield variables were also submitted to analysis of covariance and Tukey's test at $5 \%$ probability, when a significant difference was observed using the $F$-test in Microsoft Excel $2003^{\circledR}$ Software.

The analysis of variance for each site was performed considering the model: $\mathrm{Y}_{\mathrm{ij}=} \mathrm{m}+\mathrm{t}_{\mathrm{i}}+\mathrm{b}_{\mathrm{j}}+$ $e_{i j}$, where $y_{i j}$ refers to the value observed in treatment $\mathrm{i}$ in repetition $\mathrm{j} ; \mathrm{m}$ is the overall mean; $\mathrm{t}_{\mathrm{i}}$ is the effect of treatment $\mathrm{i} ; \mathrm{b}_{\mathrm{j}}$ is the effect of block $\mathrm{j}$; and $\mathrm{e}_{\mathrm{ij}}$ is the effect of the plot (error) associated with treatment $i$ in repetition $j$. The analysis of covariance was performed considering the model: $\mathrm{y}_{\mathrm{ijk}}=\mathrm{m}+\mathrm{t}_{\mathrm{i}}+\mathrm{a}_{\mathrm{j}}$ $+\mathrm{ta}_{\mathrm{ij}}+\mathrm{b}_{\mathrm{k}(\mathrm{j})}+\mathrm{e}_{\mathrm{ik}(\mathrm{j})}$, where $\mathrm{y}_{\mathrm{ijk}}$ refers to observation $k$ of treatment $i$ in environment $j$; $t_{i}$ is the effect of treatment $i$; $a_{j}$ is the effect of environment $j$; ta $a_{i j}$ is 
the effect of the interaction between treatment $i$ and environment $\mathrm{j} ; \mathrm{b}_{\mathrm{k}(\mathrm{j})}$ is the effect of block $\mathrm{k}$ within environment $j$; and $e_{i k(j)}$ is the mean error.

For the study variables, with the exception of flowering, the ratio between the largest and the smallest mean-squared residue was lower than seven for the two environments, which meets the requirement for the implementation and interpretation of the analysis of covariance (PIMENTEL-GOMES, 1990).

\section{Results and Discussion}

The analysis of covariance showed significant effects between the environments for the variables shoot height, root length, root diameter, total yield, commercial yield and harvest index (Table 3 ). The effects between cultivars were significant for shoot height, root dry matter, total dry matter, root diameter, and total yield. For the effect of the environment $\times$ cultivar interaction, differences were only observed for shoot height; therefore, for this variable, the behavior of the cultivars is not consistent with the assessed environments. These results are similar to those of Silva et al. (2012) and Carvalho et al. (2014). This interaction occurs due to different sensitivities of genotypes to environmental changes, and it is an aggravating factor in plant breeding programs (RAMALHO et al., 1993).

Table 3. Sources of variation and their degrees of freedom and mean squares for a joint analysis of variance with eight variables and an individual analysis of variance with carrot cultivars as a variable in the cities of Diamantina, MG and Couto de Magalhães de Minas, MG. UFVJM, Diamantina, 2013.

\begin{tabular}{|c|c|c|c|c|c|}
\hline \multirow[b]{2}{*}{ Source of variation } & \multirow[b]{2}{*}{ Degree of freedom } & \multicolumn{3}{|c|}{ Mean squares for the assessed variables } & \multirow[b]{2}{*}{ MST } \\
\hline & & ALT & COMP & MSR & \\
\hline Block/city & 4 & $8.97^{\mathrm{ns}}$ & $2.04^{\mathrm{ns}}$ & $139.75^{\mathrm{ns}}$ & $166.41^{\mathrm{ns}}$ \\
\hline City & 1 & $3926.17^{* *}$ & $86.86^{* *}$ & $28.36^{\mathrm{ns}}$ & $567.51^{\mathrm{ns}}$ \\
\hline Cultivars & 5 & $51.19^{* *}$ & $9.60^{\mathrm{ns}}$ & $788.01^{*}$ & $1373.84^{*}$ \\
\hline Interaction & 5 & $47.52^{* *}$ & $2.47^{\mathrm{ns}}$ & $247.65^{\mathrm{ns}}$ & $458.15^{\mathrm{ns}}$ \\
\hline Residue & 20 & 7.91 & 3.57 & 251.23 & 342.45 \\
\hline Source of variation & Degrees of freedom & DIAM & PRODT & PRODC & $\mathrm{IC}$ \\
\hline Block/city & 4 & $0.26^{\mathrm{ns}}$ & $21.26^{\mathrm{ns}}$ & $17.02^{\mathrm{ns}}$ & $18.45^{\text {ns }}$ \\
\hline City & 1 & $2.29^{* *}$ & $900.14^{* *}$ & $2805.40^{* *}$ & $672.68^{* *}$ \\
\hline Cultivars & 5 & $0.52^{* *}$ & $288.14^{*}$ & $123.90^{\mathrm{ns}}$ & $18.98^{\mathrm{ns}}$ \\
\hline Interaction & 5 & $0.11^{\text {ns }}$ & $33.79^{\mathrm{ns}}$ & $111.90^{\mathrm{ns}}$ & $40.88^{\mathrm{ns}}$ \\
\hline \multirow[t]{2}{*}{ Residue } & 20 & 0.06 & 72.17 & 65.12 & 18.79 \\
\hline & \multicolumn{5}{|c|}{$\%$ FLOR $^{*}$} \\
\hline Source of variation & \multicolumn{2}{|c|}{ Degree of freedom } & \multicolumn{2}{|c|}{ Couto de Magalhães de Minas } & Diamantina \\
\hline Block & \multicolumn{2}{|c|}{2} & \multicolumn{2}{|c|}{$4.29^{\mathrm{ns}}$} & $14.71^{\mathrm{ns}}$ \\
\hline Cultivars & \multicolumn{2}{|l|}{4} & \multicolumn{2}{|c|}{$1.54^{\mathrm{ns}}$} & $285.80^{* *}$ \\
\hline Residue & \multicolumn{2}{|l|}{8} & \multicolumn{2}{|c|}{1.80} & 32.77 \\
\hline
\end{tabular}

${ }_{\mathrm{ns},}{ }^{\mathrm{e}}{ }^{* *}=$ Not significant, significant at 5 and $1 \%$, respectively.

The premise for making the joint analysis was not observed for the character $\%$ FLOR.

The individual analysis of environments for the variable flowering percentage showed a significant effect between the cultivars only in Diamantina
(Table 3), but for shoot height among cultivars in the environments, the means of all genotypes were higher in Couto de Magalhães de Minas (Table 4). 
For the comparison between cultivars in Couto de Magalhães de Minas, the tallest shoots were found for the cultivar Brasília, which were taller than those of the cultivars Nantes, Esplanada and Tornado. For the same comparison in Diamantina, the shortest shoots were shown by the cultivar Nantes, which differed from those of the other cultivars except for Brasília. Lopes et al. (2008) also reported that the cultivar Brasília was taller than the other cultivars in an experiment in Mossoró, $\mathrm{RN}$, and concluded that this difference is probably due to an inherent property of the cultivars.

The evaluation of root length between environments showed that roots in Diamantina had a higher mean length $(24.95 \mathrm{~cm})$ than those in Couto de Magalhães de Minas $(21.84 \mathrm{~cm})$, as shown in Table 5. Lima and Athanázio (2008) in Londrina, PR, Resende et al. (2005), in Marília, SP and Reghin and Duda (2000) in Ponta Grossa, PR, observed mean root lengths of $18.55 ; 17.46$; and $13.2 \mathrm{~cm}$, respectively when examining carrot yield in a single environment. These values are lower than those observed in the present study, which is expected, since the environments and the cultivars were different to those used in this study. The mean values found in the study locations here belong to "class 22" - the class that classifies the longest roots for marketing purposes (CEAGESP, 2013).

Table 4. Mean shoot height $(\mathrm{cm})$ from the pooled analysis of carrot cultivars from Diamantina, MG and Couto de Magalhães de Minas, MG. UFVJM, Diamantina, 2013.

\begin{tabular}{lcc}
\hline Cultivars & Couto de Magalhães & Diamantina \\
\hline Brasília & $61.77 \mathrm{aA}$ & $32.55 \mathrm{bAB}$ \\
Nantes & $50.85 \mathrm{aB}$ & $26.79 \mathrm{bB}$ \\
Kuronan & $54.65 \mathrm{aAB}$ & $34.99 \mathrm{bA}$ \\
Esplanada & $51.74 \mathrm{aB}$ & $37.64 \mathrm{bA}$ \\
Planalto & $57.49 \mathrm{aAB}$ & $34.79 \mathrm{bA}$ \\
Tornado & $51.21 \mathrm{aB}$ & $35.63 \mathrm{bA}$ \\
\hline CV $(\%)$ & 6.33 & 6.33 \\
\hline
\end{tabular}

Means not followed by the same uppercase and lowercase letters in columns or rows differ according to the Tukey test at $5 \%$ probability. The coefficient of variation was estimated from the mean residual joint analysis.

Table 5. Total yield (TY); root length (LEN); harvest index (HI); root diameter (RD); and commercial yield (CY) from the joint analysis of carrot cultivars for the cities of Diamantina, MG and Couto de Magalhães de Minas, MG. UFVJM, Diamantina, 2013.

\begin{tabular}{|c|c|c|c|c|c|}
\hline City & TY $\left(\right.$ t.ha $\left.^{-1}\right)$ & LEN (cm) & HI & RD (cm) & CY (t.ha' $\left.{ }^{-1}\right)$ \\
\hline Couto de Magalhães & $47.64 \mathrm{~A}$ & $21.84 \mathrm{~B}$ & $72.91 \quad \mathrm{~B}$ & $32.61 \mathrm{~A}$ & $49.06 \mathrm{~A}$ \\
\hline Diamantina & $38.23 \mathrm{~B}$ & $24.95 \mathrm{~A}$ & $81.55 \mathrm{~A}$ & $27.57 \mathrm{~B}$ & $31.40 \mathrm{~B}$ \\
\hline CV (\%) & 26.20 & 8.52 & 6.07 & 8.54 & 20.10 \\
\hline
\end{tabular}

Means not followed by the same letters in columns differ according to the Tukey test at $5 \%$ probability. The coefficient of variation for each variable was estimated from the mean residual joint analysis.

The genotype Planalto showed the highest mean root dry matter, (62.72), which was much greater than that for Tornado and Nantes (30.68 and 33.14, respectively) (Table 6). A similar finding was also observed by Teófilo et al. (2009), in Mossoró, RN, where cultivars that had a more pronounced shoot growth also had higher values of root dry matter. 
Table 6. Mean root dry matter (RDM); total dry matter (TDM); root diameter (RD); and total yield (TY) from the joint analysis of carrot cultivars in the cities of Diamantina, MG and Couto de Magalhães de Minas, MG. UFVJM, Diamantina, 2013.

\begin{tabular}{|c|c|c|c|c|}
\hline Cultivars & RDM (g.pl-1) & TDM (g.pl-1) & RD (cm) & TY $\left(\right.$ t.ha' $\left.{ }^{-1}\right)$ \\
\hline Brasília & $41.77 \mathrm{AB}$ & $53.09 \mathrm{~B}$ & $3.32 \mathrm{~A}$ & $39.27 \mathrm{AB}$ \\
\hline Nantes & 33.14 B & $42.31 \mathrm{C}$ & $2.88 \mathrm{AB}$ & 35.43 B \\
\hline Kuronan & $39.34 \quad \mathrm{AB}$ & $51.18 \mathrm{~B}$ & $3.21 \mathrm{~A}$ & $47.06 \mathrm{AB}$ \\
\hline Esplanada & $45.77 \mathrm{AB}$ & $61.94 \mathrm{~A}$ & $2.65 \mathrm{~B}$ & $42.34 \mathrm{AB}$ \\
\hline Planalto & $62.72 \mathrm{~A}$ & $80.90 \mathrm{~A}$ & $3.25 \mathrm{~A}$ & $54.04 \mathrm{~A}$ \\
\hline Tornado & $30.68 \mathrm{~B}$ & $39.30 \mathrm{C}$ & $2.72 \mathrm{~B}$ & $49.83 \mathrm{AB}$ \\
\hline CV $(\%)$ & 38.13 & 34.41 & 8.12 & 19.24 \\
\hline
\end{tabular}

Means not followed by the same letters in columns differ according to the Tukey test at 5\% probability. The coefficient of variation for each variable was estimated from the mean residual joint analysis.

The highest mean harvest index (81.55) was observed at Diamantina (Table 5); a longer cultivation time was required at this location for the roots to reach the point of harvest, compared with at Couto de Magalhães de Minas, which had a mean harvest index of 72.91 .

For root diameter, the cultivars Brasilia, Planalto and Kuronan could be distinguished from Esplanada and Tornado (Table 6), and the plants at Couto de Magalhães de Minas had a higher mean root diameter than those at Diamantina (Table 5). Bernardi et al. (2004) and Reghin and Duda (2000) also found variations in this variable between genotypes in Braganca Paulista, SP and Reghin and in Ponta Grossa, PR, respectively. The lowest values found for the cultivar Esplanada can be explained by the fact that the breeding of this cultivar was geared towards the production of baby carrots, which resulted in the formation of thinner roots (diameter $<3 \mathrm{~cm}$ ), to ensure a greater yield in industrial production (VIEIRA et al., 2005). By contrast, the low values shown by the Tornado cultivar can be attributed to the longer life-cycle of this genotype (130 days). Furthermore, all material was harvested at 100 days after sowing, before this cultivar reached its harvest cycle (TECNOSEED, 2010).
For the total root yield, Couto de Magalhães de Minas showed a higher mean (49.06) than that of Diamantina (31.40) (Table 5). The greatest value among cultivars was shown by Planalto, but this was only significantly different from the Nantes cultivar (Table 6). Vieira et al. (2012), working with different cultivars in different regions, found a mean total root yield of 63.43 , which was higher than the value for the Planato cultivar, thus confirming the great productive potential of this new material. The cultivar Nantes showed similar results to those found in tests carried out by Luz et al. (2009) in Uberlândia, MG, and Reghin and Duda (2000) in Ponta Grossa, PR, where Nantes also showed a higher total root yield.

Nantes was the only cultivar that did not flower in the environments studied and was therefore removed from the analysis of variance for this character (Table 3). This genotype originates from France, is sensitive to mild temperatures, and is recommended for planting in cold seasons of the year. It is also highly resistant to bolting, which is the main problem in autumn-winter carrot cultivation in Brazil (EMBRAPA, 2013).

A similar result for the cultivar Nantes was found by Cardoso and Della Vecchia (1995), in Braganca Paulista, SP, who observed no bolting in different 
months of sowing for three consecutive years. Therefore, when cultivated at different sowing dates in Brazil, the cultivar Nantes showed no yield loss due to bolting, even in environments with lower temperatures, such as Diamantina (Table 1).

The incidence of flowering observed in Couto de Magalhaes de Minas was similar to that observed by Pessoa and Cordeiro (1997), who evaluated carrot cultivars sown in autumn-winter cultivation in Brasilia, DF, a region with higher temperatures than those in Diamantina. The genotype Tornado in Diamantina showed a higher flowering percentage than cultivars Brasília and Esplanada, with a flowering percentage close to $40 \%$. This result is similar to that found by Reghin and Duda (2000) for the genotype Kuronan in Ponta Grossa, PR, a location that similar to Diamantina, also has a mild climate.

According to information supplied by the manufacturer, the hybrid Tornado is not subject to restrictions on sowing dates (TECNOSEED, 2013); it is the only cultivar used in this study without restrictions on the growing season. However, this genotype showed the highest bolting percentage $(38.60 \%)$ of all genotypes in Diamantina and might therefore be unsuitable for seeding in colder seasons because it suffers major production losses caused by bolting in regions with a milder climate.

Among the cultivars evaluated in Diamantina, Brasília showed the lowest flowering percentage (11.68\%) (Table 7); however, for the same month of sowing, Cardoso and Della Vecchia (1995), in Brasilia, DF, and Reghin and Duda (2000), in Ponta Grossa, PR, found values of 32.7 and $27.3 \%$, respectively. This demonstrates that this genotype shows variability in the flowering percentage in autumn-winter cultivation, as also demonstrated by Galvani (2008) in Botucatu, SP, Brazil. This is probably because most of the material selected from the cultivar Brasília that is available on the market, is genetically weakened, with a different varietal standard from the one originally described.
This genetic degeneration is probably due to the lack of a basic inventory of seeds purchased at Embrapa Hortaliças by some companies in the seedproducing industry (ANDRADE et al., 2003).

Table 7. Flowering percentage carrot cultivars to 100 days after sowing for the city of Diamantina, UFVJM, Diamantina, 2013.

\begin{tabular}{ll}
\hline \multicolumn{1}{c}{ Cultivars } & Diamantina \\
\hline Brasília & $11.68 \mathrm{~B}$ \\
Kuronan & $24.03 \quad \mathrm{AB}$ \\
Esplanada & $20.01 \mathrm{~B}$ \\
Planalto & $22.60 \mathrm{AB}$ \\
Tornado & $38.60 \mathrm{~A}$ \\
\hline Mean & 23.38 \\
\hline CV $(\%)$ & 24.12 \\
\hline Means not followed by the same letters differ according to the \\
Tukey test at 5\% probability.
\end{tabular}

Although flowering is of paramount importance for the production of commercial seeds by natural induction, this phenomenon causes large yield losses of commercial roots. Carrot roots quickly become very lignified after natural vernalization, even before the lengthening of the flower peduncle; thus, the onset of flowering results in the complete loss of commercial value (ALESSANDRO; GALMARINI, 2007). Thus, the cultivars that showed a high flowering percentage at this time of planting are subject to yield loss of tuberous roots. On the other hand, the flowering percentage results in Diamantina showed that this environment has a great potential to induce natural flowering in carrot plants and might thus represent an environment to produce seeds by natural vernalization using the seed-to-seed method.

In terms of variable commercial yield, although there was no difference between the means of the cultivars according to Tukey's test (Table 5), the difference between some cultivars was more than 10 t.ha $^{-1}$; these values directly affect farmers' profits from a commercial point of view. In Couto de 
Magalhães de Minas, for example, the commercial yield of the cultivars Planalto, Tornado and Kuronan was above 50 t.ha $^{-1}$, and in Diamantina, that of the cultivar Planalto was close to 38 t.ha $^{-1}$ (Table 8 ).

For the variable commercial yield, Couto de Magalhaes de Minas showed the highest mean, of 49.06 t.ha $^{-1}$ (Table 5). Lopes et al. (2008), in Mossoró, RN, and Carvalho et al. (2005) in Brasilia, $\mathrm{DF}$, also carried out studies in the autumn-winter period, whereas Luz et al. (2009), in Uberlândia, MG, conducted experiments in the springsummer period and the following mean values for commercial yield were found, respectively: 35.16; 24.93, and $25.59 \mathrm{~kg} \cdot \mathrm{ha}^{-1}$. These values are lower than those found in Couto de Magalhães de Minas (49.06) and are similar to that found in Diamantina (31.40), which shows that the values obtained in Couto de Magalhães de Minas can be considered high in comparison with those of other regions.

Table 8. Commercial yield $\left(\mathrm{t} \mathrm{ha}^{-1}\right)$ for the joint analysis of carrot cultivars from Diamantina, MG and Couto de Magalhães de Minas, Minas Gerais. UFVJM, Diamantina, 2013.

\begin{tabular}{ccc}
\hline Cultivars & Couto de Magalhães de Minas & Diamantina \\
\hline Brasília & 40.15 & 33.91 \\
Nantes & 40.32 & 30.54 \\
Kuronan & 54.59 & 28.97 \\
Esplanada & 46.02 & 30.29 \\
Planalto & 58.47 & 37.77 \\
Tornado & 54.79 & 26.93 \\
\hline CV (\%) & 8.31 & 8.31 \\
\hline
\end{tabular}

The coefficient of variation for each variable was estimated from the mean residual joint analysis.

Despite the difference between environments for the variable commercial yield, the values obtained for the crops in Diamantina are relevant because they were measured in an unfavorable period for the majority of cultivars and because they exceeded the mean Brazilian yield, which is 28.0 t.ha $^{-1}$ (EMBRAPA, 2013). A further comment concerning the results from these environments is that in contrast to expectations, the imported cultivar Nantes did not show major differences out in autumn-winter cultivation, even in Diamantina, where the majority of cultivars showed high bolting values. Thus, in these locations, it is not recommended to use seeds of imported cultivars such as Nantes for autumnwinter cultivation, but rather Brazilian cultivars (usually recommended only for the summer), because these are less expensive and offer no differences in commercial yield compared with imported cultivars. This would considerably reduce production costs in this period.

\section{Conclusions}

The cultivars Planalto, Tornado and Kuronan are the most suitable for cultivation in Couto de Magalhães de Minas, whereas in Diamantina, only the cultivar Planalto is suitable.

Couto de Magalhães de Minas is the more suitable location for the cultivation of carrots.

The climate and soil conditions in Diamantina induce flowering in most cultivars, causing a loss of commercial yield in autumn-winter cultivation.

\section{Acknowledgements}

Capes, $\mathrm{CNPq}$ and FAPEMIG for the financial support. 


\section{References}

ALESSANDRO, M. S.; GALMARINI, C. R. Inheritance of vernalization requirement in carrot. Journal of the American Society for Horticultural Science, Alexandria, v. 132, n. 4, p. 525-529, 2007.

ANDRADE, F. F.; MELO, P. C. T.; MORO, J. R. Seleção massal em duas populações de cenoura do tipo 'Brasília'. In: CONGRESSO BRASILEIRO DE OLERICULTURA, 43., 2003, Recife. Anais... Recife: ABH. CD-ROM. Disponível em: <http://www.abhorticultura.com.br $>$. Acesso em: 15 abr. 2014.

BERNARDI, W. F.; FREITAS, J. A.; SILVA, V. A. R.; TULMANN NETO, A. Avaliação de espaçamentos de cenoura para os híbridos AF845 e AF750. Acta Scientiarum, Maringá, v. 26, n. 2, p. 125-130, 2004.

CARVAlHO, A. D. F.; SILVA, G. O.; PEREIRA, R. B.; PINHEIRO, J. B. Análise de fatores e regressão bissegmentada no estudo da adaptabilidade e estabilidade de cenoura. Revista Ceres, Viçosa, MG, v. 61, n.6, p. 932-940, 2014.

CARVALHO, A. M.; JUNQUEIRA, A. M. R.; VIEIRA, J. V.; REIS, A.; SILVA, J. B. C. Produtividade, florescimento prematuro e queima-das-folhas em cenoura cultivada em sistema orgânico e convencional. Horticultura Brasileira, Vitoria da Conquista, v. 23, n. 2, p. 250-254, 2005.

CARDOSO, A. I. I.; DELlA VECCHIA, P. T. Considerações sobre o florescimento prematuro e suas implicações para o melhoramento de cenoura para primavera. Horticultura Brasileira, Vitoria da Conquista, v. 13, n. 2, p. 146-149, 1995.

COMPANHIA DE ENTREPOSTOS E ARMAZÉNS GERAIS DE SÃO PAULO - CEAGESP. Cenoura: no caminho da modernização: relatório do ano de 2000, São Paulo: Programa brasileiro para a melhoria dos padrões comerciais e embalagens de hortigranjeiros. São Paulo: Embrapa Uva e Vinho, 2015. Disponível em: <http:// www.hortibrasil.org.br/jnw/images/stories/folders/ cenoura.pdf $>$. Acesso em: 21 out. 2015.

COMISSÃO DE FERTILIDADE DO SOLO DO ESTADO DE MINAS GERAIS - CFSEMG. Recomendações para o uso de corretivos e fertilizantes em Minas Gerais: 5a Aproximação. Viçosa: SBCS, 1999. $359 \mathrm{p}$.

SERVIÇO GEOLÓGICO DO BRASIL - CPRM. Serviço geológico do Brasil: relatório do ano de 2007. Brasília: [s.n.], 2008. Disponível em: <http://www.cprm.gov.br/ publique/media/rel_anual_2007.pdf/>. Acesso em: 21 out. 2015.
CRUZ, C. D.; CASTOLDI, F. L. Decomposição da interação genótipos $\mathrm{x}$ ambientes em partes simples e complexa. Revista Ceres, Viçosa, MG, v. 38, n. 219, p. 422-430, 1991.

DUDA, C.; REGHIN, M. I. Efeito da época de semeadura em cultivares de cenoura. Publicatio UEPG. Ciências Exatas e da Terra, Ciência Agrárias e Engenharias, Ponta Grossa, v. 6, n. 1, p. 103-114, 2000.

EMPRESA BRASILEIRA DE PESQUISA AGROPECUÁRIA - EMBRAPA. Embrapa hortaliças. Agência de informação Embrapa - cenoura: relatório de 2011, Brasília: Embrapa hortaliças, 2013. Disponível em: $<$ http://www.agencia.cnptia.embrapa.br/gestor/cenoura/ arvore/CONT000gnhfy 7 ha $02 \mathrm{wx} 5$ ok0edacxlso 5 fmok. html>. Acesso em: 7 fev. 2013.

Embrapa hortaliças. Centro nacional de pesquisa de hortaliças. Brasília: Embrapa hortaliças, 2015. Disponível em: <http://www.cnph.embrapa.br/paginas/ sistemas_producao/cultivo_da_cenoura/cultivares.htm>. Acesso em: 11 ago. 2015.

Hortaliças em números: relatório do ano de 2008. Brasília: Embrapa hortaliças, 2012. Disponível em: <http://www.cnph.embrapa.br/paginas/ hortalicas_em_numeros/balanca_comercial_1997_2008. xls $>$. Acesso em: 24 jan. 2013.

FLOSS, E. Fisiologia de plantas cultivadas: o estudo que está por trás do que se vê. Passo Fundo: UPF, 2006. $751 \mathrm{p}$.

FREITAS, F. C. L.; ALMEIDA, M. E. L.; NEGREIROS, M. Z.; HONORATO, A. R. F.; MESQUITA, H. C.; SILVA, S. V. O. F. Períodos de interferência de plantas daninhas na cultura da cenoura em função do espaçamento entre fileiras. Planta Daninha, Viçosa, MG, v. 27, n. 3, p. 473480, 2009.

GALVANI, R. Variabilidade para florescimento prematuro em cenoura Brasília no cultivo de outonoinverno. 2008. Dissertação (Mestrado em Agronomia) Universidade Estadual Paulista Júlio de Mesquita Filho, Botucatu.

INSTITUTO NACIONAL DE METEOROLOGIA INMET. Dados históricos: relatório do ano de 2012. Brasília: INMET, 2012. Disponível em: <ttp://www. inmet.gov.br/portal/index.php?r=bdmep/bdmep $>$ Acesso em: 15 set. 2012 .

LARIOS, A. L.; DIAZ, C. A.; TORREGOZA, M. C.; MARTINEZ, O. W. Estabilidad fenotípica y adaptabilidad de cinco híbridos de sorgo granífero en clima caliente colombiano. I. Rendimento. Revista ICA, Medellín, v. 27, n. 1, p. 293-303, 1992. 
LIMA, C. B.; ATHANÁZIO, J. C. Caracterização comercial de raízes de cenoura de seis ciclos de seleção da variedade Londrina. Semina: Ciências Agrárias, Londrina, v. 29, n. 3, p. 507-514, 2008.

LOPES, W. A. R.; NEGREIROS, M. Z.; TEÓFILO, T. M. S.; ALVES, S. S. V.; MARTINS, C. M.; NUNES, G. H. S.; GRANGEIRO, L. C. Produtividade de cultivares de cenoura sob diferentes densidades de plantio. Revista Ceres, Viçosa, MG, v. 55, n. 5, p. 482-487, 2008.

LUZ, J. M. Q.; SILVA JÚNIOR, J. A.; TEIXEIRA, M. S. S. C.; SILVA, M. A. D.; SEVERINO, G. M.; MELO, B. Desempenho de cultivares de cenoura no verão e outonoinverno em Uberlândia-MG. Horticultura Brasileira, Vitória da Conquista, v. 27, n. 1, p. 96-99, 2009.

MICROSOFT Excel 2003 ${ }^{\circledR}$ (2003). Software pago, Microsoft corporation. [S.1. : s.n], 2003.

OLIVEIRA, C. D.; BRAZ, L. T.; BANZATTO, D.A. Adaptabilidade e estabilidade fenotípicade genótipos de cenoura. Horticultura Brasileira, Vitória da Conquista, v. 23, n. 3, p. 743-748, 2005.

ORGANIZAÇÃO DAS NAÇÕES UNIDAS PARA ALIMENTAÇÃO E AGRICULTURA - FAO. Agricultural production, primary crops. Londres: FAOSTAT, 2013. Disponível em: <http://www.fao.org>. Acesso em: 5 fev. 2013.

PESSOA, H. B. S.; CORDEIRO, C. M. T. Avaliação de cultivares de cenoura no outono-inverno no Distrito Federal. Horticultura Brasileira, Vitória da Conquista, v. 15, n. 1, p. 72-74, 1997.

PIMENTEL-GOMES, F. Curso de estatística experimental. Piracicaba: Nobel, 2000. 477 p.

RAMALHO, A. P.; SANTOS, M. B. dos; ZIRMMERMAM, M. J. de O. Genética quantitativa em plantas autógamas: aplicações ao melhoramento do feijoeiro. Goiânia: UFG, 1993. 271 p.
REGHIN, M. I.; DUDA, C. Efeito da época de semeadura em cultivares de cenoura. Ciências Exatas e da Terra, Ciência Agrárias e Engenharias, Ponta Grossa, v. 6, n. 1, p.103-114, 2000.

RESENDE, F. V.; SOUZA, L. S.; OLIVEIRA, P. S. R.; GUALBERTO, R. Uso de cobertura morta vegetal no controle da umidade e temperatura do solo, na incidência de plantas invasoras e na produção da cenoura em cultivo de verão. Ciência e Agrotecnologia, Lavras, v. 29, n. 1, p. 100-105, 2005.

SILVA, G. O.; CARVALHO, A. D. F.; VIEIRA, J. V.; FRITSCHE-NETO, R. Adaptabilidade e estabilidade de populações de cenoura. Horticultura Brasileira, Vitória da Conquista, v. 30, n. 1, p. 80-83, 2012.

TECNOSEED. Produtos: cenoura híbrida tornado: relatório do ano de 2010. Ijuí: Tecnoseed, 2010. Disponível em: $<$ http://www.tecnoseed.com.br/produtos. $\mathrm{php}$ ?tit $=$ CENOURA\& $\mathrm{t}=\& \log =\mathrm{n} \&$ filtro $=$ cenoura $>$. Acesso em: 2 fev. 2013.

TEÓFILO, T. M. S.; FREITAS, F. C. L.; NEGREIROS, M. Z.; LOPES, W. A. R.; VIEIRA, S. S. Crescimento de cultivares de cenoura nas condições de Mossoró-RN. Caatinga, Mossoró, v. 22, n. 1, p. 168-174, 2009.

VIEIRA, J. V.; SILVA, G. O.; CHARCHAR, J. M.; FONSECA, M. E. N.; SILVA, J. B. C.; NASCIMENTO, W. M.; BOITEUX, L. S.; PINHEIRO, J. B.; REIS, A.; RESENDE, F. V.; CARVALHO, A. D. F. BRS Planalto: cultivar de cenoura de polinização aberta para cultivo de verão. Horticultura Brasileira, Vitória da Conquista, v. 30, n. 2, p. 359-363, 2012.

VIEIRA, J. V.; SILVA, J. B. C.; CHARCHAR, J. M.; RESENDE, F. V.; FONSECA, M. E. N.; CARVALHO, A. M.; MACHADO, C. M. M. Esplanada: cultivar de cenoura de verão para fins de processamento. Horticultura Brasileira, Vitória da Conquista, v. 23, n. 3, p. 851-852, 2005. 
